Article

\title{
Integrating Business Students' E-Learning Preferences into Knowledge Management of Universities after the COVID-19 Pandemic
}

\author{
Dávid Máté Hargitai ${ }^{1}$, Florina Pinzaru ${ }^{2, *(\mathbb{D}}$ and Zoltán Veres ${ }^{1}$ (D) \\ 1 Department of Marketing, University of Pannonia, Egyetem utca 10, 8200 Veszprém, Hungary; \\ hargitai.david@gtk.uni-pannon.hu (D.M.H.); veres.zoltan@gtk.uni-pannon.hu (Z.V.) \\ 2 Faculty of Management, National University of Political Studies and Public Administration SNSPA, \\ bd. Expoziției 30A s.1, 012104 Bucharest, Romania \\ * Correspondence: florina.pinzaru@facultateademanagement.ro
}

check for updates

Citation: Hargitai, D.M.; Pinzaru, F.; Veres, Z. Integrating Business Students' E-Learning Preferences into Knowledge Management of Universities after the COVID-19 Pandemic. Sustainability 2021, 13, 2478. https://doi.org/10.3390/ su13052478

Academic Editor:

Constantin Bratianu

Received: 31 January 2021

Accepted: 21 February 2021

Published: 25 February 2021

Publisher's Note: MDPI stays neutral with regard to jurisdictional claims in published maps and institutional affiliations.

Copyright: (c) 2021 by the authors. Licensee MDPI, Basel, Switzerland. This article is an open access article distributed under the terms and conditions of the Creative Commons Attribution (CC BY) license (https:/ / creativecommons.org/licenses/by/ $4.0 /)$.

\begin{abstract}
The COVID-19 pandemic forced many universities to close doors and keep students completely online-a phenomenon that raised unprecedented challenges with lessons learned that should be integrated into future educational knowledge management strategies and practices. Special attention should be given to students' learning habits. This paper presents the results of a semi-systematic literature review on the research problem and a survey of a sample of business students regarding their learning habits and preferences. Learnings of the research can be useful for the transition to an entirely online distance education, integrated in the framework of knowledge management strategies regarding e-learning in universities. The primary quantitative research was conducted before the start of the lockdown, and the results give useful insights that can be translated into mandatory elements for any strategy designed to assure a smooth and effective passage from in-class education to online teaching and learning. Students' pre-epidemic learning habits, their use of communication tools and their preferences for solutions usable in distance education, with a special focus on gender and education level, have been investigated. Results are correlated in the paper with possible knowledge management strategies in universities as part of an approach with both academic and practical implications.
\end{abstract}

Keywords: online learning; e-learning systems; educational knowledge management; business education

\section{Introduction}

The first steps toward online education were made almost three decades ago, and since then universities and schools all over the world have used it for distance or part-time students. With the sudden impact of the COVID-19 pandemic and the consequent necessity to ensure physical distance, online education has become almost the norm. However, educational institutions found themselves in different states of preparation for such a challenge, beginning with the professors' mindset to aspects related to pedagogy and usage of technology, even if some of these aspects were discussed by the academic literature prior to the pandemic [1]. Organizational agility and previous experience in e-learning made a difference, being very visible in how schools and universities managed the sudden transition towards online education starting in February and March 2020.

Even before the COVID-19 pandemic, digital alternatives to classic education were a promising reality, with global EdTech investments reaching US\$18.66 billion in 2019 [2] in an overall challenged university model [3-6]. As clearly stated by Chamorro-Premuzic and Frankiewicz [3], "employers need skills, not just knowledge or titles, students want jobs, not knowledge or titles ( ... ), while many elite universities prioritize research, often at the expense of teaching". Despite technological developments and socioeconomic reconfiguration specific to digital natives' characteristics [4-6], "higher education has significantly lagged behind other industries in moving to a more digitally driven business 
model ( . . ), with less than 5\% of college budgets ( ... ) dedicated to IT spending" [7]. The COVID-19 pandemic catalyzed what was emerging as a generic reality affecting simultaneously almost all educational institutions. University faculties of Humanities and Economics found themselves in an apparently better situation, as investments in digital technologies necessary for generalized distance learning seemed to be lesser than in the case of technical and vocational schools. Nevertheless, business schools should expect soon an IT moderated transformation based on the antecedents of "the transformations of the university, the business world and the student" [8].

In response to the call for understanding of lessons learned by business schools in the context of the COVID-19 pandemic, the present paper focuses on the multifocal triad of elearning, transformation of students and knowledge management. Students' preferences in the online environment as compared to their learning habits in the traditional educational one are correlated with other lessons learned during the pandemic for future practical knowledge management strategies in universities.

To address the above issues, this study has three purposes: (1) exploring knowledge management strategies related to e-learning; (2) investigating the transformation of business students from the perspective of their learning habits; (3) formulating recommendations on how to integrate students' transformation, understood from the perspective of their learning habits, into knowledge management strategies in business schools in the context of COVID-19. The main research problems can be formulated as follows:

1) What is the status of knowledge management as a practice in educational institutions, particularly in universities/business schools, related to e-learning?

2) What are the learning practices of students in the digital environment, as compared to the classical one, in higher education systems?

As the first research phase, a semi-systematic literature review was performed, and two research gaps were identified, affirmed by a series of expert focus group discussions: gender specific e-learning preferences on one hand and probable differences by education levels on the other. The following phase, a quantitative survey, therefore aimed to explore these statistical significances, among others. Based on the findings from the semi-systematic literature review and the quantitative study conducted on business students regarding their learning habits and preferences, the authors discuss knowledge management in universities, applying the lessons learned from the transition to online education.

The paper has both theoretical and practical implications. The findings are useful in defining some possible efficient practices for passing from the traditional education framework to a digital one, considering students' learning preferences, and thus being usable for educational managers in the context of the COVID-19 pandemic.

\section{Literature Review}

In the literature review section the article briefly presents the concepts of e-learning and knowledge management in education, the most important related theories, the applicable teaching methods using online platforms and students' and teachers' perceptions of online teaching and communication in order to understand the topic as widely as possible and to contrast it with the challenges specific to business education.

\subsection{Literature Review Methodology}

This paper uses a variant of semi-systematic literature review to get a deeper insight into the above research problems. The use of the semi-systematic review allows us "to identify and understand all potentially relevant research traditions that have implications for the studied topic" [9]. A thematic analysis of the most relevant concepts and narratives related to e-learning, knowledge management in educational institutions and student transformation was conducted. To synthesize the state of knowledge on the topic, articles, book chapters and conference proceedings were selected from international academic databases, as well as reports and studies published by international organizations (UNESCO, WHO), consultancy firms (McKinsey, Deloitte), and educational publishers (McGraw-Hill). The 
literature presented in Table 1 frames the following aspects: (1) the advantages and disadvantages of e-learning, the satisfaction and trust associated with e-learning, the relationship with the digital divide and the current technological challenges; (2) the knowledge management practices of universities; (3) the student transformation and learning preferences in the current digitalized context.

Table 1. Literature review main results.

\begin{tabular}{|c|c|}
\hline \multicolumn{2}{|c|}{ Studies on e-learning } \\
\hline $\begin{array}{l}\text { Studies on the benefits and disadvantages of e-learning } \\
\text { in higher education }\end{array}$ & Almaiah et al. [10]; Arkorful and Abaidoo [11]; Cantoni et al. [12] \\
\hline $\begin{array}{l}\text { Studies about satisfaction levels and trust related to } \\
\text { e-learning }\end{array}$ & Pharm et al. [13]; Goh et al. [14]; Paechter et al. [15]; Sun et al. [16] \\
\hline Studies on e-learning and the digital divide & $\begin{array}{l}\text { Sepulveda for UNESCO [17]; Correia for WHO [18]; Muresan and } \\
\text { Gogu [19]; Journell [20] }\end{array}$ \\
\hline $\begin{array}{l}\text { Studies on technology advances in e-learning (mobile, } \\
\text { augmented reality, artificial intelligence, etc.) }\end{array}$ & McKinsey [21]; Deloitte [22] \\
\hline \multicolumn{2}{|c|}{ Studies on knowledge management in higher education } \\
\hline $\begin{array}{l}\text { Studies on the relationship between knowledge } \\
\text { management and organizational performance and } \\
\text { innovation }\end{array}$ & $\begin{array}{l}\text { Gold et al. [23]; Liao and Wu [24]; López-Nicolás and Meroño-Cerdán } \\
\text { [25]; Ngah et al. [26] }\end{array}$ \\
\hline $\begin{array}{l}\text { Studies on the framework of knowledge management in } \\
\text { higher education }\end{array}$ & $\begin{array}{l}\text { Rowley [27]; Kidwell et al. [28]; Akhawan et al. [29]; Townley [30]; } \\
\text { Mahdi et al. [31]; Iqbal et al. [32]; Muqabas et al. [33]; Ramjeawon and } \\
\text { Rowley [34]; Bratianu [35]; Gurteen [36]; Tan [37]; Chugh [38] }\end{array}$ \\
\hline \multicolumn{2}{|c|}{ Studies on knowledge management practices in e-learning systems } \\
\hline $\begin{array}{l}\text { Studies on online learning and knowledge-based } \\
\text { educational environment }\end{array}$ & $\begin{array}{l}\text { Alharti et al. [39]; Petrides and Nodine [40]; Tessier and Dalkir [41]; } \\
\text { Campbell [42]; Weichhart et al. [43] }\end{array}$ \\
\hline $\begin{array}{l}\text { Studies on knowledge management in distance learning } \\
\text { institutions }\end{array}$ & Sharifzadeh and Safari [44]; Ras et al. [45] \\
\hline \multicolumn{2}{|c|}{ Studies on student transformation and learning preferences } \\
\hline $\begin{array}{l}\text { Studies on students as stakeholders of educational } \\
\text { institutions }\end{array}$ & $\begin{array}{l}\text { Krishnamurthy [8]; Al Shehab [46]; Nunez et al. [47]; Guilbault [48]; } \\
\text { Nixon et al. [49]; Bovill [50]; Ricci et al. [51]; Pack and Peek [52] } \\
\text { McGraw-Hill Education [53]; Rogowski et al. [54]; Vagg et al. [55]; } \\
\text { Severiens and Ten Dam [56]; Keri [57]; Francis [58]; Alkhasawneh et al. } \\
\text { [59]; Demirbas and Demirkan [60]; Sarabi-Asiabar et al. [61]; Al-Saud } \\
\text { [62]; Cetin and Erel [63]; Dalmolin et al. [64]; Othman et al. [65]; } \\
\text { Demirkan [66]; Matthews [67]; Garber [68]; Yousef [69]; Gappi [70]; } \\
\text { Kolb [71]; Felder and Soloman [72]. }\end{array}$ \\
\hline
\end{tabular}

\subsection{Studies on E-Learning}

There is no generally accepted definition of the term "e-learning". In a general sense, e-learning means any form of learning that is available electronically and includes a wide range of computer-based educational platforms, educational material sharing methods and forms of educational materials such as multimedia materials, simulations and games. To evaluate an e-learning system, it is necessary to examine the advantages and disadvantages for its users. Based on the literature, it can be concluded that e-learning has several benefits in higher education: flexibility in terms of time and place [10], cost-effectiveness by reducing expenses associated with physical facilities and transport, and opportunities for students to progress at their own pace $[10,11]$. The smaller learning units generally found in elearning can contribute to a better understanding of the content [12] and a more lasting learning effect, while the mix of digital instruments enhances students' participation and collaboration. Although e-learning has advantages when used in education, it equally has disadvantages: a negative impact on socialization skills [11], increased possibility of fraud in exams, expensive investments in technology [11] and costly new digital skills 
that become necessary and that can increase the digital divide in the case of both students and teachers.

Satisfaction and trust in e-learning systems are influenced by the quality of the service itself, measured through specific elements such as the e-learning administrative and support service quality, the instructor quality, the accuracy of the teaching process, the course materials quality, and e-learning security and privacy [13]. An important instrument to evaluate satisfaction levels associated with e-learning is the research of perceptions of students and teachers involved in the process. The design and flexibility of the course, the interaction with the teacher and with other students and variety of online evaluation methods are salient predictors of satisfaction in e-learning, as reported by Goh et al. [14] and consistent with the findings of Paechter et al. [15] and of Sun et al. [16], while the technology itself seems to have a neutral influence [16]. Adapting instruction to the online environment is a critical factor for motivating students [15], and therefore the instructor's expertise in e-learning plays a major role in the students' evaluations of the quality of e-learning [16]. The instructor's role is critical in creating a sufficient level of satisfaction among students and is expressed both by the ability to teach and by attitude [16]. Therefore, there are two important elements that should be considered when selecting teachers for e-learning: their expertise in the field in which they teach and their attitude toward computers and educational platforms [16]. Aspects such as the adoption of new pedagogical instruments and the adapting of content and interactions, all of which integrated into teachers' continuous training for e-learning, are similarly important elements such as technological investments. These aspects increase the level of trust in distance education using digital instruments.

The COVID-19 pandemic revealed that e-learning, even if discussed and practiced for more than 25 years and continuously updated with new forms of technology, is still influenced by a digital divide. One of the most cited difficulties regarding the online education in 2020 was the lack of access to the Internet for categories of population in many parts of the world. As mentioned in a recent report of UNESCO [17], connectivity and access to information are of outmost importance for today's young population, and they cannot exist without affordable and reliable Internet access. Besides being an answer to the sustainability goal of reducing inequalities, investing in school's connectivity all over the world could be a source of revenue for different stakeholders [17], from telecom wholesale and retail operators to surrounding communities. Bridging the digital gap to ensure equal access to digitalized education is critical for any development strategy, as proved by the COVID-19 pandemic [18]. However, it remains a source of challenges for the expansion of e-learning for, among others, (a) students who are not connected to Internet and (b) teachers who are not trained for digitalized education. These factors were also discussed before the pandemic $[19,20]$. By promoting e-learning both for students and for adults oriented toward continuing education, universities can bridge a part of the digital divide, and thus can develop adults' digital skills [19]. As highlighted by Journell [20], educators should try various solutions to address technological inequity, including increasingly creative ideas when the issue is more complex, such as combating digital illiteracy or socioeconomic inequality. E-learning's characteristic of creating online communities is mentioned by Journell [17] as a possible solution to decrease the divides that exist between students from opposite social classes, as students who are actively involved in online communities tend to share more information, which leads to improved class participation. Therefore, they are less likely to feel alienated and subsequently choose to continue education and to not drop out. However, special skills as well as school policies and strategies are necessary for such outcomes; otherwise, the entire process remains random and depends on the individual skills and involvement of teachers.

E-learning evolves with technology, and the most recent studies [21,22] emphasize new possibilities for education by using mobile technologies, artificial intelligence (AI), the Internet of Things (IoT), etc. As seen by the reality of the COVID-19 pandemic and as discussed previously in the literature [21], digital natives (young generations growing 
up with internet access) use smartphones and/or tablets mostly for information and for access to online classes. Therefore, education using mobile technologies should be a norm for any e-learning system, visible at least at the level of adapted content (e-books and ecourses), mobile-friendly virtual classrooms and mobile-friendly gaming and collaboration instruments [21]. If the adaptation of mobile systems seems to be a necessity for the moment, AI-based education is still developing; however, it is expected to impact teaching on a large scale, with possible opportunities raised by the future usage of big data. At present, AI applications in education can cover such aspects [22] as intelligent adaptive learning (for example, virtual teachers allowing students to have completely individualized learning processes), intelligent searches (computer vision and image recognition), speech assessment, and intelligent language processing application. It is expected [22] that AI-based education will make individualized education possible, therefore putting the student's individual needs at the center of the process and thus creating a framework for better learning outcomes. We can predict that new forms of knowledge management will be needed in this respect, both for learner data models and for integrating AI into educational strategies.

\subsection{Studies on Knowledge Management in Higher Education}

Knowledge management (KM) is believed to be an essential element of any organization and even more so in the case of educational providers such as universities. Addressing aspects such as knowledge acquisition, knowledge conversion, and knowledge application, which are inherent to any knowledge management framework [23], KM implementation proves the ability of an organization to acquire, convert, and apply specific knowledge [24] as a possible part of any strategy oriented toward innovation and performance. In the case of higher education, the debates on the readiness of universities for structured KM are already two decades old $[25,26]$. By nature, higher education institutions abound in repositories of knowledge, both printed and electronic, and provide access to them as a fundamental part of their mission [25]. However, being a university does not mean that an organization is an efficient example of KM strategies and practices, and thus, for possible translations of $\mathrm{KM}$, the best examples could be found in corporations [26]. For Lee and Roth [27], four dimensions are relevant to translate KM from theory to practice in higher education: leadership, culture, technology and measurement. In this respect, leadership refers to integrating high quality and relevant data to make decisions, while culture refers to creating a team mindset of empowerment and sharing knowledge inside the university. As for technology, Lee and Roth [27] highlight the necessity that educational leaders reflect on the ways in which universities can find resources and design adequate processes to create, share and transfer knowledge. KM is useful, according to the same authors [27], for the design and subsequent improvement of evaluation processes as well as for the measurement of efficiency and effectiveness of educational institutions.

One of the debated aspects of KM both in general and specifically in the case of higher education is the fact that many believe it useful; therefore, while conceptual models are proposed [27,28], KM is difficult operationalize. Higher education was one of the sectors initially slow in implementing knowledge management practices [28]. However, KM's importance in practice has recently grown, mostly in universities looking for competitive advantages in the educational market or in terms of positioning in various research rankings [29,30]. In such organizations, one of the most efficient KM enablers remains a knowledge-friendly culture [31]. Authors have distinctive opinions and results when discussing the effects of knowledge management on organizational performance (OP). For instance, López-Nicolás and Meroño-Cerdán [32] consider knowledge processes as not directly influencing organizational performance, while Ngah et al. [33] estimate that there could be a correlation between KM and OP through lenses of the innovation driven by KM processes. Other enablers of KM in higher education are the quality and experience of the staff, the existence of incentives (like access to study leave, payment of conference fees, etc.), and the availability of an adequate technical infrastructure [34]. 
Universities should be learning entities [35], not only providers of knowledge for students. While studies on empirical situations of concrete KM strategies remain scarce, research on the topic highlights the importance of knowledge sharing (KS), mostly to put together individual knowledge that already exists in universities but is not corroborated for maximum efficiency [36]. Tan [37] states that while KS in universities may be a major process in KM strategies, it depends mostly on the university's organizational culture, and thus further depends on the direct support and involvement of top management. This can be achieved by identifying and promoting the right incentives for KS-positive behaviors. Moreover, KM can lead to effective interpersonal communication, which enhances trust, refuels the KS process, and creates the appropriate environment for collaboration and, consequently, for academic outcomes leading to organizational performance. Such findings support the previous conclusions of Chugh [38], who signaled that universities no longer support tacit knowledge transfer, at least not explicitly, mainly for technical and cultural reasons. Moreover, even if managers are cited in almost all studies as an important factor in any process of knowledge management, they seem to be a deterrent in the transfer of tacit knowledge at some universities [38]. As a general idea, a common aspect arises from many studies on KM in universities: it is necessary, must be supported publicly by managers, and should focus both on formal aspects and on informal elements related to trust, communication, openness and collaboration.

\subsection{Studies on Knowledge Management Practices in E-Learning Systems}

The relationship between knowledge management and e-learning systems can be understood from a double perspective: KM thinking is useful to develop robust e-learning systems (ideally, both performant and sustainable), and e-learning systems can provide an appropriate framework for KM development.

An e-learning system can be defined as "an educational solution to deliver knowledge, facilitate learning and improve performance by creating, using and managing appropriate technological processes and resources", according to Alharti et al. [39]. Sustainable e-learning systems include three quality models: product quality (with sub-characteristics such as functional suitability, performance efficiency, compatibility, usability, reliability, security, maintainability, portability and greenability); data quality and quality in use [39]. Online education creates many new opportunities to broaden the educational environment and to develop knowledge management strategies that can provide a framework for understanding how and where to focus energy to improve educational outcomes, given the goals and mission of the organization [40]. E-learning-based knowledge management improves knowledge transfer between students and the institution [41]. The knowledge-based educational environment has been extremely dynamized by the application of interactive online technologies. Online learning goes beyond the planned subject learning and recognizes the value of students' self-management [42]. E-learning makes individualized learning possible, but such an approach is effective only if teachers restructure the way they prepare their class [43]. Weichart et al. [43] state that better outcomes can be achieved in the framework of a technology through initial personal socialisation of students, which is consistent with Journell's previous findings [20].

As discussed above, trust and communication are mandatory elements for any effective knowledge sharing process. Sharifzadeh and Safari [44] show that, in some cases of distance learning universities, the fact that there is a good internal climate for implementing $\mathrm{KM}$ theories as well as the existence of mechanisms and tools to convert tacit knowledge into explicit knowledge, make the use of knowledge a relevant factor in achieving organizational performance. The success of distance learning universities does not derive exclusively from the quality of technology deployed in the e-learning systems; instead, it comes mostly from the existence of a high intellectual capital [44], a finding consistent with previous studies on KM performance at universities in general $[19,20,36]$.

Integrating knowledge management and e-learning systems seems difficult in practice. Ras et al. [45] cite barriers such as problems on a conceptual or technical level, the existence 
of neglecting learning processes, problems related to the amount of guidance provided, problems of context neglect or of structuring and annotating content, a lack of interactivity, and problems of dynamic adaptation and of content not being cognitively adequate. Overcoming the constraints of $\mathrm{KM}$ and e-learning systems integration is possible through the adoption of competence management or the integration of working and learning on a process level [45].

Such recommendations are even more relevant in the context of the COVID-19 pandemic, when e-learning became mandatory, and therefore many students, teachers and educational managers found themselves unprepared for such a transition. One of the challenges related to e-learning in such a situation is knowledge retention, which could be improved if KM practices specific to e-learning best practices are integrated by education providers. Some of these best practices are listed in Al Shehab [46]: simple and clear virtual sessions; usage of various multimedia tools, gamification, and virtual simulations; usage of platforms convenient for both students and teachers; collecting lessons learned from students after each meeting; repeating information; encouraging students' engagement and collaboration by stimulating communication and teamwork; increasing students ${ }^{\prime}$ self-learning.

\subsection{Studies on Digitally Driven Student Transformation}

Digitally driven student transformation is a concept that encompasses multiple facets of the changes in the beliefs, opinions, and behaviors of higher education students due to societal and technological factors. Addressed either as a future challenge [8] or as a current reality, driven by digitalization in general as well as by e-learning and MOOCs (massive online open courses) in particular [47], it captures the most important modifications in the students' expectations and preferences regarding teaching and learning.

Understanding how students relate to educational processes is compulsory for any managerial strategy, as students are considered university stakeholders. Students as stakeholders in higher education is a phenomenon addressed by the academic literature in various dimensions: students as beneficiaries of educational services [8] — sometimes in a controversial customer-oriented paradigm [48,49]; students as partners [50]; students playing simulated stakeholders' roles [51]; a form of engaging students [52]. All these approaches are relevant for managerial strategies in higher education institutions, especially for adapting curriculum and teaching and for engaging students in university communities.

The current students enrolled in higher education institutions are, in most cases, digital natives; thus, their preference toward learning through technology is no surprise, nor is their expectation that teaching uses more digital instruments, as they tend to find them "very or extremely helpful in their academic life, particularly for doing class research and completing assignments" [53]. Students are generally categorized, depending on their learning style, as visual or auditory learners [54]. Adapting teaching to learning styles is generally recommended but remains controversial in terms of efficiency [54]. Digital natives tend to prefer to learn using digital learning technology (DLT), such as laptops [53] and multimedia [55]. Smartphones used for connection in the educational process are not perceived as learning instruments [53].

There is very little information on the learning preferences of students related to gender and education level that could be extrapolated into generic managerial strategies through the lenses of knowledge management. Previous studies on students learning preferences are older [56-60], do not cover current digital preferences or are individualized to specific fields of activity, such as medicine and health [61-64], mathematics [65], interior architecture [66], etc. Matthews revealed a significant difference among learning styles according to the discipline of study [67], while Severiens and Dam [56] emphasized the context's role in influencing the learning preferences of female and male students.

The recent literature on addressing business students' learning preferences is scarce. Garber et al. discuss "the gender differences in learning style revealed by attitudinal response to participation in serious business games" [68] and conclude that "female partic- 
ipants show themselves to be concrete experiencers (CE), viewing themselves as learners who are accepting, feeling and receptive graspers of experience, while male participants are abstract conceptualizers (AC), viewing themselves as learners who are logical, analytical and present-oriented graspers of experience" [68]. There is no relevant difference in learning style preferences by gender among statistics students according to Youssef [69] and Gappi [70] when measuring the specific four dimensions defined by Kolb [71] and Felder and Soloman [72]: active/reflective, sensing/intuitive, visual/verbal and sequential/global.

\subsection{Identification of Research Gaps-A Qualitative Exploration}

Our semi-systematic literature review addressed four major areas: e-learning, knowledge management in universities, relationship between knowledge management and e-learning systems, and digitally driven student transformation. The findings suggest that there is a need to explore the knowledge management strategies and practices related to e-learning systems from the various stakeholders' perspectives. One group of stakeholders is students; their learning preferences and habits should be understood and integrated into sustainable KM of e-learning systems provided by universities. The aforementioned studies point to a research gap in addressing business students' learning preferences of usage of education materials in the current digitalized context: perspectives of gender and education levels. Exploring such aspects would be useful in the context of a knowledge management framework that could be used to support strategies of higher education institutions in the field of business studies.

Considering the above-explained research gaps and the lack of information on business students' learning preferences of usage of education materials in the current digitalized context, three expert focus group discussions (FGDs) were organized with 18 teachers in business and economics, which took place between 26 and 28 February 2020 at the University of Pannonia, Hungary, in the context of the possible expansion of the COVID-19 pandemic. The FGD qualitative method was used to validate certain results of the literature research and to identify factors that could play a significant role in students' e-learning preferences. The main topics of the discussion scenario were as follows:

- Recognition of the benefits of e-learning techniques in the traditional educational culture, or so-called hybridization.

- $\quad$ Efficiency of knowledge transfer in the light of students' e-learning preferences.

- Educational experience of the differentiation of e-learning preferences.

On the basis of the analysis of the discussion transcripts, it was a unanimous opinion that, despite the relative heterogeneity of the literary antecedents, there is a clear shift towards more advanced communication technologies in business higher education. Another strong argument was that gender-related learning attitudes also determine e-learning preferences, as was partly the case in previous studies. Business educators highlighted that, in their experience, learning preferences also show a significant difference according to educational levels (bachelor's degree, master's degree, postgraduate training and doctoral programs). Although no relevant source was found, different profiles of students by level of training (age, business practice, focus of interest, etc.) makes the differentiation of e-learning preferences probable.

The conclusions of the FGDs were used to formulate propositions from which research hypotheses were defined.

\section{Hypothesis Development}

Based on the research gaps identified in the literature review phase and on the propositions formulated in the FGDs, the following hypotheses were developed regarding business students' learning habits and use of info-communication tools as well as preferences for solutions that can be used in distance education:

- H1: Significant difference by gender can be detected in the students' use of the Internet for learning materials. 
- H1a: Men are less likely to use learning materials through the Internet.

- H1b: Women are more likely to use learning materials through the Internet.

- H2: Students at lower (bachelor's) levels of education used the Internet to learn more often than students learning at higher (master's) levels.

- H3: Tangible materials are preferred by women more than by men (regardless of course type).

- H4: Tangible materials are preferred by students at lower (bachelor's degree) levels of education more than by master's students.

These hypotheses are the result of the pre-studies performed by the research team and have no antecedents in literature, as the research gap subchapter of this paper highlights. The FGDs were based on educational experiences that were not covered in the literature but proved to be necessary for relevant knowledge strategies to be implemented in the new pandemic context.

\section{Quantitative Study: Business Students' Learning and Internet Use Habits as a Part of KM Strategies for E-Learning}

Developing and maintaining an e-learning system can be costly and raises numerous challenges, as mentioned previously. Despite the expansion of e-learning during the last few decades, before the COVID-19 pandemic there were still universities reluctant to use e-learning on a large scale, and they found themselves forced to make a rapid transition to online distance learning without being prepared. The transfer from in-class teaching to online platforms requires both specific capacities and a solid knowledge of students learning and Internet-use habits.

In this respect we conducted research among the students in Business and Economics at the University of Pannonia, Hungary, investigating their preferences for adequate online learning solutions. We defined the following research questions:

- RQ1: What is the nature of the learning habits and practices of students in a traditional educational environment?

- $\quad$ RQ2: How often do students use the opportunities provided by the Internet during the learning process?

- RQ3: What forms of learning materials (paper and/or electronic) do students prefer?

- RQ4: Are there any differences between the training levels and genders in relation to the above research questions?

\subsection{Quantitative Study Methodology}

Primarily, it is necessary to know how students use the Internet for learning. Furthermore, it is important to know which tools they use and which educational materials they prefer. In this respect we conducted research among students in business and economics on their preferences for solutions that can be used in distance education based on online instruments. A theoretical model of the quantitative research was created in parallel to the formulation of the hypotheses (Figure 1), which presents two segmentation criteria: (1) a gender analysis in relation to learning support materials and (2) differences by training levels. This was followed by a preliminary research phase. The next phase was the primary research, aimed at finding out the student's preferences and opinions about the forms of learning. The indirect intention of the research was a practical one, namely, to use the research results to customize distance education. 


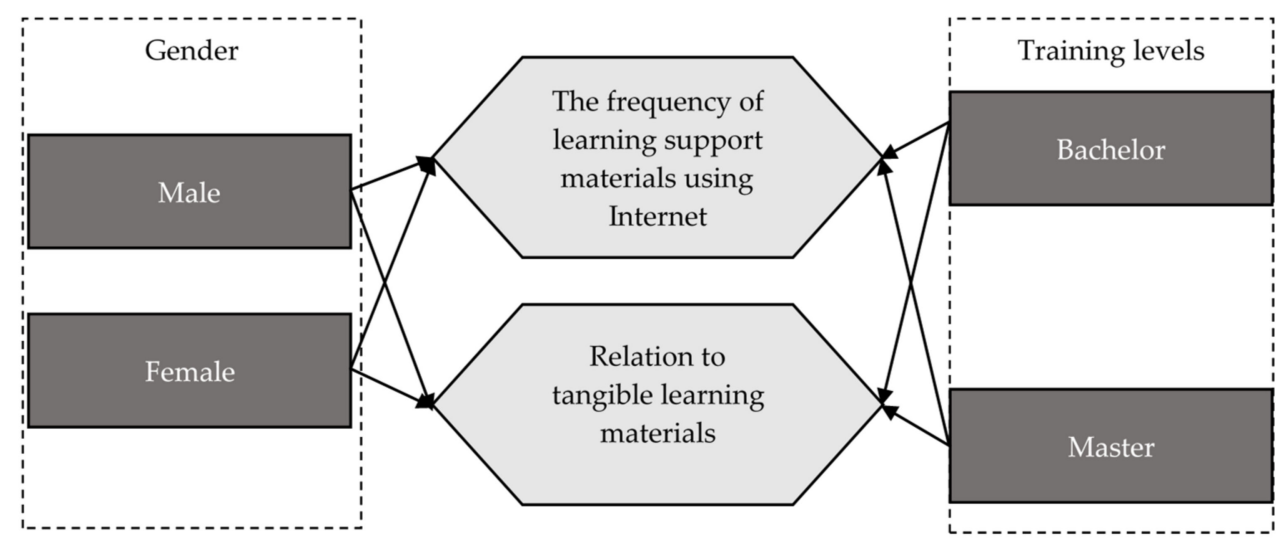

Figure 1. Theoretical model of the quantitative research.

To obtain data faster, we compiled an online questionnaire in the LimeSurvey questionnaire editing platform. The questions were divided into four groups (general learning; student relationship with info-communication tools; distance learning-independent learning-e-learning; demography). Afterward, the questionnaire was tested by educational experts with experience in quality assurance. The final version of the questionnaire integrated their suggestions as well as the necessary corrections of formal and linguistic anomalies. The questionnaire was sent via e-mail to students actively enrolled mostly in bachelor's and master's studies in business and economics.

Univariate and multivariate statistical methods were used to verify the hypotheses. Descriptive statistics were used to obtain the primary characteristics of the sample. During the cross-tabulation correlation analysis in the case of nominal scales, the coefficient $\Phi$ was used. The Levene test was applied to verify the identity of population variances. In the cases where this condition was not met (so-called heteroskedasticity), instead of the twosample $t$-test, the Welch test was used, as this method analyzes the same null hypotheses and does not require the match of standard deviations.

\subsubsection{Characteristics of the Sample}

All 1701 students actively enrolled in educational programs in Business and Economics at the University of Pannonia, Hungary, were involved in the research (total population as gross sample size). The questionnaire was emailed to the total population of 1701 students and was completed by 1181 respondents. After data cleaning, 959 responses were considered relevant for analysis, from which 825 were fully completed, while 134 people provided partial responses to the questionnaire. The average response time was $9 \mathrm{~min}$, which was exactly the same as our preliminary assumptions. The survey was completed between 18 and 24 March 2020. The quantitative analysis was performed with SPSS Statistics 21.0 and Microsoft Excel 2013.

Table 2 shows the demographics relevant to the study. These data provided segmentation criteria for analysis. The results of the frequency distributions in the examined sets show that the sample is considered to be reasonably representative in terms of gender, level of training/academic program and the form of education.

\subsubsection{Definition of Terms}

In this study, two basic levels of education were considered: the lower level of education means bachelor's programs, while the higher one means master's programs. The frequency of use of the Internet for learning purposes was measured by six levels. The respondents could choose from the following options: (1) several hours per day (three or more hours); (2) one or two hours each day; (3) several times a week; (4) a few times a month; (5) a few times a semester; (6) never. 
Table 2. The characteristics of the sample.

\begin{tabular}{ccccc}
\hline Segmentation Criterion & Subset & $\begin{array}{c}\text { Total } \\
\text { Population }\end{array}$ & Subset & $\begin{array}{c}\text { Total } \\
\text { Population }\end{array}$ \\
\hline $\begin{array}{c}\text { Level of education }(\mathrm{N}=825) \\
\begin{array}{c}\text { Higher education vocational } \\
\text { training programs }\end{array}\end{array}$ & 147 & 374 & 18 & 22 \\
\hline Postgraduate training & 19 & 47 & 2 & 3 \\
\hline Bachelor's program & 534 & 1008 & 65 & 59 \\
\hline Master's program & 118 & 224 & 14 & 14 \\
\hline Doctoral program & 7 & 28 & 1 & 2 \\
\hline Gender $(N=825)$ & & & 28 & 33 \\
\hline Male & 233 & 582 & 72 & 66 \\
\hline Female & 592 & 1119 & & 60 \\
\hline Form of education $(\mathrm{N}=959)$ & 628 & 1004 & 65 & 40 \\
\hline Full-time & 331 & 697 & 35 & \\
\hline Part-time & & & \\
\hline
\end{tabular}

\subsection{Quantitative Study Results}

The results refer to a subset of the complete database, as assumptions were determined by the level of education. In the present research, the goal was to explore the differences between bachelor's and master's students; therefore, the number of the subset was 652 $(\mathrm{N}=652)$. The validity of the first and second hypotheses was examined using the Crosstabs test. It is important to note that variables from Likert scales-as a compromise-were considered to be interval variables when computing the averages. The tests of the analysis were checked as shown in Table 3. The frequency of learning support materials using the Internet, by gender and education level, was studied on an interval scale (reading of learning material, solving computational tasks, preparation of report/submission, note taking/voice recording, and searching information).

The condition of homogeneity of variance is only fulfilled in the case of gender as a group variable at the training level; it is not fulfilled in the case of reading, taking notes, and recording audio. In these cases, the $t$-values of the Welch d-test were considered. Based on the paired-sample $t$-test, it can be stated that, according to the gender as well as the level of education, the average/mean of the two groups differs significantly in terms of solving the computational tasks $(\mathrm{t}(650)=-2.648, p=0.008 ; \mathrm{t}(650)=-1.924, p=0,050)$. The mean frequency of female students was 3.48 (standard deviation $=0.967$ ) and the frequency of male students was 3.21 (standard deviation $=1.076$ ). According to the education level, the average frequency of the bachelor's students was 3.36 (standard deviation $=1.169$ ) and the same value of the master's students was 3.58 (standard deviation $=1.172$ ). The correlation of the results obtained was supported by Chi-square statistics because the significance level was below $p<0,005$. Gray background indicates significances. 
Table 3. Examining the relationship between variables.

\begin{tabular}{|c|c|c|c|c|c|c|}
\hline & & $\begin{array}{c}\text { Reading of } \\
\text { Learning Materials }\end{array}$ & $\begin{array}{c}\text { Solving } \\
\text { Computational } \\
\text { Tasks }\end{array}$ & $\begin{array}{c}\text { Preparation of } \\
\text { Reports/Submissions }\end{array}$ & $\begin{array}{c}\text { Note } \\
\text { Taking/Voice } \\
\text { Recording }\end{array}$ & $\begin{array}{l}\text { Searching } \\
\text { Information }\end{array}$ \\
\hline & & \multicolumn{5}{|c|}{$N=652$} \\
\hline \multirow{2}{*}{$\begin{array}{c}\text { Normal } \\
\text { Parameters } \\
\text { a, b }\end{array}$} & Average & 2.89 & 3.40 & 3.07 & 4.16 & 2.69 \\
\hline & Deviation & 1.002 & 1.172 & 1.028 & 1.563 & 0.903 \\
\hline \multicolumn{2}{|c|}{ Kolmogorov-Smirnov test } & 6.595 & 6.129 & 6,279 & 5.277 & 7.288 \\
\hline \multicolumn{2}{|c|}{ two-sided significance } & 0.000 & 0.000 & 0.000 & 0.000 & 0.000 \\
\hline \multirow{2}{*}{$\begin{array}{l}\text { Levene's F-test } \\
\quad \text { (gender) }\end{array}$} & F value & 10.676 & 2.060 & 1.568 & 2.082 & 1.219 \\
\hline & significance & 0.001 & 0.152 & 0.211 & 0.150 & 0.270 \\
\hline \multirow{2}{*}{$t$-test } & t value & -1.721 & -2.648 & -1.066 & -1.143 & -0.361 \\
\hline & significance & 0.086 & 0.008 & 0.287 & 0.287 & 0.718 \\
\hline \multicolumn{2}{|c|}{ Chi-squared test (gender) } & 0.079 & 4.559 & 0.455 & 1.396 & 0.373 \\
\hline \multicolumn{2}{|c|}{ significance } & 0.779 & 0.033 & 0.500 & 0.237 & 0.542 \\
\hline \multirow{2}{*}{$\begin{array}{l}\text { Levene's F-test } \\
\text { (education level) }\end{array}$} & F value & 0.048 & 0.116 & 3.217 & 3.898 & 1.220 \\
\hline & significance & 0.826 & 0.734 & 0.073 & 0.049 & 0.270 \\
\hline \multirow{2}{*}{$t$-test } & t-value & -0.940 & -1.924 & 0.671 & 0.544 & -0.718 \\
\hline & significance & 0.349 & 0.050 & 0.503 & 0.586 & 0.473 \\
\hline \multicolumn{2}{|c|}{ Chi-squared test (training level) } & 1.334 & 5.908 & 0.021 & 0.002 & 0.186 \\
\hline \multicolumn{2}{|c|}{ significance } & 0.248 & 0.015 & 0.885 & 0.965 & 0.666 \\
\hline
\end{tabular}

For reasons of clarity, the interval scale of learning supporting tasks was transformed into a nominal variable. According to the time factor, it was divided in two parts, as presented in Table 4:

- Weekly: three or more hours per day, one or two hours per day, several times a week;

- Less frequently: a few times per month (2-3 times), a few times per every six months (2-3 times), never.

Table 4. Frequency distribution of calculation tasks by gender and level of education.

\begin{tabular}{cccc}
\hline \multirow{2}{*}{ Description } & \multicolumn{2}{c}{ Computational Tasks } & \multirow{2}{*}{ Total } \\
\cline { 2 - 3 } & Weekly & Less Frequently & \\
\hline Male & by gender & & \\
\hline Female & 130 & 64 & 194 \\
\hline SUM & 266 & 192 & 458 \\
\hline Distribution & 396 & 256 & 652 \\
\hline Male (\%) & & & \\
\hline Female $(\%)$ & 67 & 33 & 100 \\
\hline SUM & 58 & 42 & 100 \\
\hline
\end{tabular}


Table 4. Cont.

\begin{tabular}{|c|c|c|c|}
\hline \multirow{2}{*}{ Description } & \multicolumn{2}{|c|}{ Computational Tasks } & \multirow{2}{*}{ Total } \\
\hline & Weekly & Less Frequently & \\
\hline \multicolumn{4}{|c|}{ \% within computational tasks } \\
\hline Male $(\%)$ & 33 & 25 & 30 \\
\hline Female $(\%)$ & 67 & 75 & 70 \\
\hline SUM & 100 & 100 & 100 \\
\hline$\Phi$ ratio & & $0,084(0,033)$ & \\
\hline \multicolumn{4}{|c|}{ by educational level } \\
\hline Bachelor & 336 & 198 & 534 \\
\hline Master & 60 & 58 & 118 \\
\hline SUM & 396 & 256 & 652 \\
\hline \multicolumn{4}{|l|}{ Distribution } \\
\hline Bachelor $(\%)$ & 63 & 37 & 100 \\
\hline Master (\%) & 51 & 49 & 100 \\
\hline SUM & 61 & 39 & 100 \\
\hline \multicolumn{4}{|c|}{ \% within computational tasks } \\
\hline Bachelor $(\%)$ & 85 & 77 & 82 \\
\hline Master (\%) & 15 & 23 & 18 \\
\hline SUM & 100 & 100 & 100 \\
\hline$\Phi$ ratio & & $0.084(0.033)$ & \\
\hline
\end{tabular}

In the case of males, the proportion of solving computational tasks via the Internet was slightly more regular on a weekly basis $(67 \%)$ as compared to females $(58 \%)$. This difference can be explored equally at the education level. For bachelor's students, $63 \%$ were solving computational tasks via the Internet on a weekly basis, while only $51 \%$ of master's students did the same. The existence of a relationship between the two factors was demonstrated by the significance level of Chi-square. In both cases, $p$ was less than 0,005 ; therefore a relationship exists. Table 4 also includes the indicator $\Phi$, showing that there was a weak significant relationship between gender and education level in the case of computational task solving via the Internet.

Students' reading and learning habit characteristics in the period before the introduction of pandemic restrictions were mapped, as we wanted to know students' preferences concerning practical lessons (seminars) and lectures in general. To determine their opinions, four statements were provided, and they had to rate them on a scale of one to six:

- I like books and photocopies the most because I can take them with me.

- I can learn from my own notes, but they are not enough for every exam.

- I have learned from electronic learning materials, but it is hard for me.

- Multimedia materials are particularly good; I can learn better if there are figures and the materials are guided through in practice.

Table 5 summarizes the results related to the assumptions (hypotheses 3 and 4). First, the frequencies were examined for the statements. To highlight the differences, the six-point scale was transformed into three units in which the most common response categories per statements were highlighted with gray background.

Considering these frequency statistics, we can see a statistically (moderately) strong correlation (Spearman's rank correlation) between the seminars and lectures in the case of books, photocopies and multimedia materials $\left(R_{\text {books, photocopies }}=0.669 ; R_{\text {multimedia materials }}=0.832\right)$. 
According to student opinions, both activities appear to be more relevant in the case of practical education. The gender and the education level were included as segmentation criteria. In order to carry out a statistical exploration of differences, a two-sided $t$-test was performed.

Table 5 contains the result of the $t$-test. Where the standard deviation homogeneity was not fulfilled, we considered the t-values of Welch's d-test. The values of the average deviation were indicated in the case where the result of the $t$-test showed a significant difference within the categories of the group variable. If we classify the results as segmentation factors, we can make the following statements: books and photocopies are typically preferred by women for seminars and lectures. The value of average difference compared to men is almost the same in both cases $(-0.7)$. The results of learning from one's own notes are similar to the previous statement. In this case, it is more common for women to take and learn their own notes, but the average deviation is smaller in the case of the use of photocopies and books. The following area is also in line with the previous findings. Men have less difficulty in handling electronic learning materials (average seminar $=2.67$; average $_{\text {lecture }}=2.54$ ). It is more difficult for women (average seminar $=3.44$; average $_{\text {lecture }}=3.26$ ), because they prefer tangible materials to support learning. A difference can be seen at the level of popularity of books and photocopies between bachelor's and master's students (average deviation $=0.574$ ). This result is only valid statistically in the case of seminars (practical lessons) (average value bachelor $=4.46$; average value $_{\text {master }}=3.88$ ). Bachelor's students find the manageability of e-learning materials more difficult (average value seminar $=3.29$; average value lecture $=3.12$ ) than master's students (average value $_{\text {seminar }}=2.84$; average value lecture $\left.=2.62\right)($ regardless of course type).

Table 5. Segmented results of learning habits.

\begin{tabular}{|c|c|c|c|c|c|c|c|c|c|c|c|}
\hline & \multirow{2}{*}{$\begin{array}{l}\text { Average } \\
\text { Deviation }\end{array}$} & \multirow{2}{*}{$t$-Test } & \multicolumn{3}{|c|}{ Seminar } & \multirow{2}{*}{ Statement } & \multicolumn{3}{|c|}{ Lecture } & \multirow{2}{*}{$t$-Test } & \multirow{2}{*}{$\begin{array}{l}\text { Average } \\
\text { Deviation }\end{array}$} \\
\hline & & & 1 & 2 & 3 & & 1 & 2 & 3 & & \\
\hline gender & -0.733 & $\begin{array}{l}-5.423 \\
0.000\end{array}$ & \multirow{2}{*}{$\begin{array}{l}109 \\
17 \%\end{array}$} & \multirow{2}{*}{$\begin{array}{l}189 \\
29 \%\end{array}$} & \multirow{2}{*}{$\begin{array}{l}354 \\
54 \%\end{array}$} & \multirow{2}{*}{$\begin{array}{l}\text { I like books and photocopies the most } \\
\text { because I can take them with me. }\end{array}$} & \multirow{2}{*}{$\begin{array}{l}153 \\
23 \%\end{array}$} & \multirow{2}{*}{$\begin{array}{l}207 \\
32 \%\end{array}$} & \multirow{2}{*}{$\begin{array}{l}292 \\
45 \%\end{array}$} & $\begin{array}{l}-5.542 \\
0.000\end{array}$ & -0783 \\
\hline $\begin{array}{c}\text { education } \\
\text { level }\end{array}$ & 0.574 & $\begin{array}{l}3.470 \\
0.001 \\
\end{array}$ & & & & & & & & $\begin{array}{l}1.591 \\
0.115\end{array}$ & - \\
\hline gender & -0.433 & $\begin{array}{c}-3.776 \\
0.000 \\
\end{array}$ & \multirow{2}{*}{$\begin{array}{c}61 \\
9 \%\end{array}$} & \multirow{2}{*}{$\begin{array}{l}240 \\
37 \%\end{array}$} & \multirow{2}{*}{$\begin{array}{l}351 \\
54 \%\end{array}$} & \multirow{2}{*}{$\begin{array}{l}\text { I can learn from my own notes, but } \\
\text { they are not enough for every exam. }\end{array}$} & \multirow{2}{*}{$\begin{array}{c}66 \\
10 \%\end{array}$} & \multirow{2}{*}{$\begin{array}{l}250 \\
38 \%\end{array}$} & \multirow{2}{*}{$\begin{array}{l}336 \\
52 \%\end{array}$} & $\begin{array}{l}-3.136 \\
0.002\end{array}$ & -0.360 \\
\hline $\begin{array}{l}\text { education } \\
\text { level }\end{array}$ & - & $\begin{array}{c}-1.331 \\
0.191\end{array}$ & & & & & & & & $\begin{array}{c}-0.434 \\
0.665\end{array}$ & - \\
\hline gender & -0.770 & $\begin{array}{l}-5.607 \\
0.000\end{array}$ & \multirow{2}{*}{$\begin{array}{l}271 \\
42 \%\end{array}$} & \multirow{2}{*}{$\begin{array}{l}194 \\
30 \%\end{array}$} & \multirow{2}{*}{$\begin{array}{l}187 \\
29 \%\end{array}$} & \multirow{2}{*}{$\begin{array}{c}\text { I have learned from electronic } \\
\text { learning materials, but it is hard for } \\
\text { me. }\end{array}$} & \multirow{2}{*}{$\begin{array}{l}300 \\
46 \%\end{array}$} & \multirow{2}{*}{$\begin{array}{c}202 \\
31 \%\end{array}$} & \multirow{2}{*}{$\begin{array}{l}150 \\
23 \%\end{array}$} & $\begin{array}{l}-5.385 \\
0.000\end{array}$ & -0.715 \\
\hline $\begin{array}{l}\text { education } \\
\text { level }\end{array}$ & 0.449 & $\begin{array}{l}2.763 \\
0.006\end{array}$ & & & & & & & & $\begin{array}{l}3.204 \\
0.002\end{array}$ & 0.501 \\
\hline gender & - & $\begin{array}{l}1.209 \\
0.227 \\
\end{array}$ & \multirow{2}{*}{$\begin{array}{l}31 \\
5 \%\end{array}$} & \multirow{2}{*}{$\begin{array}{l}156 \\
24 \%\end{array}$} & \multirow{2}{*}{$\begin{array}{c}465 \\
71 \%\end{array}$} & \multirow{2}{*}{$\begin{array}{l}\text { Multimedia materials are very good; I } \\
\text { can learn better if there are figures } \\
\text { and the materials are guided through } \\
\text { in practice. }\end{array}$} & \multirow{2}{*}{$\begin{array}{l}38 \\
6 \%\end{array}$} & \multirow{2}{*}{$\begin{array}{l}180 \\
28 \%\end{array}$} & \multirow{2}{*}{$\begin{array}{l}434 \\
67 \%\end{array}$} & $\begin{array}{l}1.669 \\
0.096\end{array}$ & - \\
\hline $\begin{array}{l}\text { education } \\
\text { level }\end{array}$ & - & $\begin{array}{c}-0.326 \\
0.745\end{array}$ & & & & & & & & $\begin{array}{c}-1.022 \\
0.307\end{array}$ & - \\
\hline
\end{tabular}

\subsection{Empirical Findings}

The first hypothesis was not, or partially, confirmed: learning support materials are utilized more by men on a weekly basis using the Internet. Furthermore, a significant difference could only be interpreted for the computational tasks. The second hypothesis was partly confirmed: bachelor's students deal with computational tasks on a weekly basis, whereas master's students are less likely to do this activity using the Internet. We were able to confirm our third hypothesis, as women prefer tangible learning materials both for photocopies and books and for their own notes. There was also a difference in terms of education level, but only in the case of books and photocopies. The independence of the course type was not fulfilled in this context. In light of the above-mentioned facts, the fourth hypothesis was partially confirmed. The results are summarized in Figure 2. 


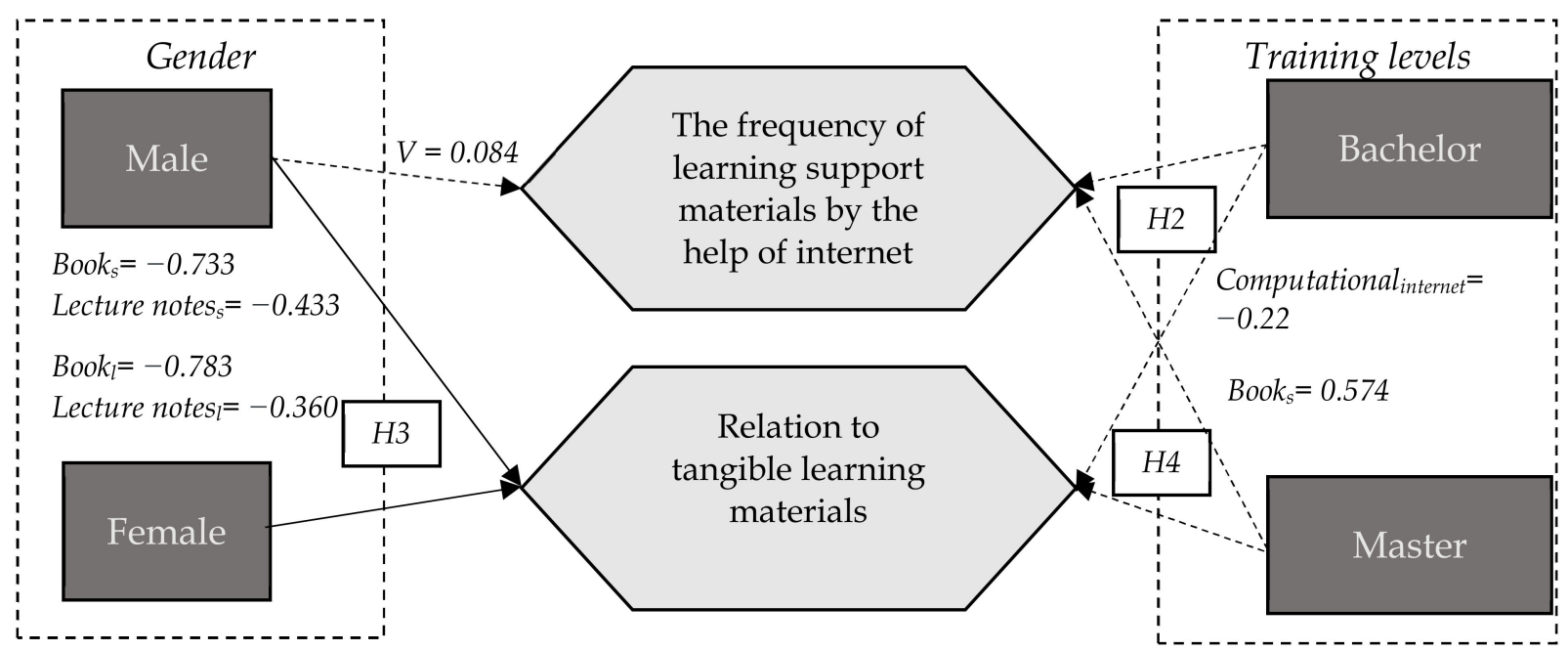

Figure 2. Results of the quantitative research.

\section{Discussion}

The COVID-19 pandemic is a catalyst for the digital transformation of learning, accelerating the transition from classical education toward online-based teaching and learning. Universities had to adapt in a very rapid rhythm to the realities of mass e-learning during 2020, and consequent lessons must be learned and integrated for any future strategies. An efficient way to act would be to develop knowledge management frameworks in which specific current e-learning challenges could be integrated. Velásquez and Lara [73] highlight that such an endeavor is influenced by the KM maturity in universities, and that various recommendations for future policies and improvements apply at three levels: human capital, structural capital and relational capital. The COVID-19 pandemic affected mostly relational capital, specifically, the connections between students [73]. However, more generally, it changed teaching methods in universities, and therefore students' learning habits and preferences should be studied further in the future and incorporated into managerial plans.

Today's university students tend to use the Internet extensively to communicate and for entertainment; recently, they prefer to rely even more on social media for information gathering and feedback [74]. Moran et al. [75] identified online video as the most popular form of social media both for teaching in class and as supplementary sources posted outside class for student use, followed by podcasts and blogs. YouTube was confirmed as a possible source for academic learning by Moghavvemi et al. [76] in the case of relevant content, being associated with the development of critical thinking if effectively used (i.e., ensuring the ability of students through teachers' guidance to critically evaluate the specific resources) [77]. A positive impact of YouTube usage in education on students' learning outcomes and satisfaction was confirmed by Orus et al. [78], a fact partially explainable by the preference of students to watch short videos instead of orienting themselves towards contextual content [79]; these findings were also confirmed by our quantitative research.

Where YouTube is widely used as a source for teaching and learning, issues are more complex as compared to other social media. For instance, Facebook groups tend to be a source of information, but students do not always feel safe and comfortable about their privacy [80], have mixed perceptions on the effectiveness of Facebook course pages that instructors manage [81], or do not use Facebook at all, only other social media (Instagram, Tik-Tok) and only for personal communication and entertainment purposes.

In the absence of previous investigations, the primary research presented in this article introduces new aspects to the literature. Based on the empirical quantitative results, we recommend the sharing of practical assignments with students on a weekly basis; sending or uploading tasks or learning materials more often is not advisable. If more and more materials are uploaded every day or more times per week, the students will perceive that 
it is too much to review at one time. At the same time, a lot of information about the learning materials in an educational framework can be confusing. Master's students are less likely to use the Internet for searching learning information. This fact is due to their higher training level and their prior learning experience. For bachelor's students, it is recommended that additional learning aids be applied that can be shared inside or outside the learning platform through direct links.

Given the findings in the second half of the empirical research, we confirmed our third hypothesis, according to which women prefer tangible materials regardless of the course type. This aspect is new in literature, as previous studies have considered gender differences mostly as slight [56]. However, other authors have identified the direct effects of gender on students' scores in different aspects, such as the approaches to studying inventory [82] or visualization as a learning preference of students studying accounting and finance [83].

Hypothesis 4 can only be accepted partially because bachelor's students showed a significant difference only in the level of popularity of books and photocopies (tangible materials) from master's students. Moreover, the validity of this statement is true only for seminars (practical classes). The acceptance of the hypothesis (partially) is also supported by the attitudes towards electronic materials. It shows that master's students have fewer difficulties as compared to bachelor's students in managing these types of materials, regardless of the course type. These findings add new insights to previous studies on the variety of university students' preferences that can predict and classify learning styles, such as the ones of Göğüş and Ertek [84,85]. Nevertheless, they are consistent with studies that confirmed necessary caution when interpreting differences in learning preferences' changes across years of study [86].

\section{Integrating Students Learning Preferences and Habits into Knowledge Management Strategies of E-Learning and Blended Learning after the COVID-19 Pandemic-Some Conclusions}

Future post-COVID-19 KM strategies at universities should consider some important aspects related to students' preferences and learning habits. Among them, we can integrate elements mentioned by previous studies as well as findings from our quantitative research:

- Mandatory integration of multimedia materials in teaching, mostly of video materials, and secondly of audio options, considering students' usage of YouTube as the dominant form of social media preferred for learning;

- A balanced mix of tangible and digital resources recommended for/requested from students, ideally interchangeable, considering the specific preferences we found between female and male students and between bachelor's and master's students;

- Pedagogical updates for teachers on how to use digital educational platforms and how to manage classes, evaluation, and communication with students;

- A balanced rhythm of practical assessments, with specific attention given to the uploading and posting schedules, ideally on a weekly basis;

- Training for teachers on how to stimulate connectivity and engagement in virtual classes with respect to students' privacy concerns.

Depending on organizational cultures and levels of KM maturity, universities could use the above-mentioned aspects as suggestions, recommendations, or critical steps in designing or adapting KM processes as part of KM strategies. Knowledge management is used by universities as a pillar to achieve competitive advantages, and the COVID-19 pandemic proved even more its importance. However, KM could lead to limited outcomes if it were used by universities' management mostly in the direction of updates in technology. Dynamic management studies, as discussed by Nicolescu and Nicolescu [87], suggest the importance of flexible managerial mindset when designing strategies and implementing processes. Thus, considering all aspects (investments in technology, investments and human capital, attention to relational capital and to students' preferences and learning 
habits) could ensure the goal of successful knowledge management in universities as a source of performance.

\section{Summary, Limitations, and Future Studies}

A fast transition of higher education to online education during the last year happened as a result of the social distancing required to combat the COVID-19 pandemic. Lecturers, researchers and students showed unprecedented unity and cooperation in meeting the challenge, trying to gather and implement the best possible solutions by supporting one another. More than ever, the practical necessity of knowledge management proved its relevance for universities. However, successful KM is reliant on organizational cultures and processes that improve the abilities, capabilities, and motivations of individualsstudents and staff in the case of higher education institutions. In this paper we explored what lessons should be learned by universities after the sudden and general transition from classical education to distance education online. Therefore, we discussed the overall relationship between knowledge management in universities and e-learning in the attempt to discover relevant insights that could put students' learning preferences and habits into a managerial context. Our quantitative study on business students' pre-epidemic learning, corroborated with conclusions on e-learning habits, gives valuable information to teachers and educational managers for the future. Nevertheless, we are aware that other functions of higher education may need to be transformed, depending on the duration of the epidemic.

Overall, it is recommended that the form of the given materials should be chosen in accordance with the education level and the gender composition of the class participants. In the case of bachelor's students (where female students are in the majority) it is advisable to compile materials that contain a continuous, printable text, at least for seminars (practical lessons). Audio materials can also be a solution for female students. They can make their own notes and can learn effectively based on them.

As with any academic research, this paper has limitations. One of these is that the collection of data of the quantitative study was finished almost at the same time as the start of the lockdown in Europe, and thus students expressed opinions that were also related to classical education. However, this limitation is also an opportunity, as the findings are relevant for blended learning, which we believe will be used more than before following the COVID-19 pandemic. Another limitation is the composition of the sample, with business and economics students from one university. Possible cultural influences on their learning habits can be addressed by future studies.

This paper makes an important contribution to knowledge management studies by addressing the lessons that universities should learn and translate into managerial frameworks after the usage of extensive e-learning systems as a result of the COVID-19 pandemic. The key contributions of the paper fall into three main areas. First, it adds to existing research on business students' learning preferences and habits with respect to the influence of the Internet. Thus, we found it important to explore the key opinions in connection with online teaching and generic learning activities, and our results contain useful and usable findings depending on the education level, the gender composition of the student cohorts and the type of courses. Second, the paper explores the relationship between knowledge management and e-learning in the case of universities, highlighting the role of top management and the constraints of KM maturity. Third, our findings can be used for future academic studies as well as to make practical improvements and develop a culture and processes that promote and implement concrete KM measures and actions after the COVID-19 pandemic in universities with respect to students' opinions regarding elearning and, more generally, learning habits. Finally, this paper provides a detailed picture of knowledge management at universities specifically related to e-learning and integrates the findings into valuable managerial insights that consider students' learning preferences.

Author Contributions: Conceptualization, D.M.H., F.P. and Z.V.; methodology, D.M.H. and Z.V.; software, D.M.H.; validation, D.M.H. and Z.V.; formal analysis, D.M.H. and Z.V.; investigation, D.M.H., F.P. and Z.V.; resources, D.M.H., F.P. and Z.V.; data processing, D.M.H.; writing-original 
draft preparation, F.P. and D.M.H.; writing—review and editing, F.P.; visualization, F.P.; supervision, Z.V.; project administration, Z.V.; funding acquisition, D.M.H., F.P. and Z.V. All authors have read and agreed to the published version of the manuscript.

Funding: We acknowledge the financial support of Széchenyi 2020 under the EFOP-3.6.1-16-201600015.

Institutional Review Board Statement: The study was conducted according to the guidelines of the Declaration of Helsinki, and approved by the Ethics Committee of the Faculty of Business and Economics, University of Pannonia (GTK-EB 20/07; 10.03.2020).

Informed Consent Statement: Respondents' consent was waived due to the anonymous questioning in which research subjects cannot be identified.

Data Availability Statement: https://www.gtk.uni-pannon.hu/wp-content/uploads/2021/02/ database_research.sav, accessed on 31 January 2021.

Conflicts of Interest: The authors declare no conflict of interest.

\section{References}

1. Urdan, T.A.; Weggen, C.C. Corporate e-Learning: Exploring a New Frontier; WR Hambrecht Co.: San Francisco, CA, USA, 2000.

2. Li, C.; Lalani, F. The COVID-19 Pandemic Has Changed Education Forever. This is How. World Economic Forum. 2020. Available online: https:/ / www.weforum.org/agenda/2020/04/coronavirus-education-global-covid19-online-digital-learning/ (accessed on 25 August 2020).

3. Chamorro-Premuzic, T.; Frankiewicz, B. 6 Reasons Why Higher Education Needs to Be Disrupted. Harvard Business Review, 2019. Available online: https:/ /hbr.org/2019/11/6-reasons-why-higher-education-needs-to-be-disrupted(accessed on 7 February 2021).

4. Flavin, M.; Quintero, V. UK higher education institutions' technology-enhanced learning strategies from the perspective of disruptive innovation. Res. Learn. Technol. 2018, 26. [CrossRef]

5. Shah, R.K.; Barkas, L.A. Analysing the impact of e-learning technology on students' engagement, attendance and performance. Res. Learn. Technol. 2018, 26. [CrossRef]

6. Aparicio, M.; Bacao, F.; Oliveira, T. An e-learning theoretical framework. Educ. Technol. Soc. 2016, 19, $292-307$.

7. Gallagher, S.; Palmer, J. The Pandemic Pushed Universities Online. The Change Was Long Overdue. Harvard Business Review, 2020. Available online: https://hbr.org/2020/09/the-pandemic-pushed-universities-online-the-change-was-long-overdue (accessed on 7 February 2021).

8. Krishnamurthy, S. The future of business education: A commentary in the shadow of the Covid-19 pandemic. J. Bus. Res. 2020, 117, 1-5. [CrossRef]

9. Snyder, H. Literature review as a research methodology: An overview and guidelines. J. Bus. Res. 2019, 104, 333-339. [CrossRef]

10. Almaiah, M.A.; Al-Khasawneh, A.; Althunibat, A. Exploring the critical challenges and factors influencing the E-learning system usage during COVID-19 pandemic. Educ. Inf. Technol. 2020, 25, 5261-5280. [CrossRef]

11. Arkorful, V.; Abaidoo, N. The role of e-learning, advantages and disadvantages of its adoption in higher education. Int. J. Instr. Technol. Distance Learn. 2015, 12, 29-42.

12. Cantoni, V.; Cellario, M.; Porta, M. Perspectives and challenges in e-learning: Towards natural interaction paradigms. J. Vis. Lang. Comput. 2004, 15, 333-345. [CrossRef]

13. Pham, L.; Williamson, S.; Berry, R. Student perceptions of e-learning service quality, e-satisfaction, and e-loyalty. Int. J. Enterp. Inf. Syst. 2018, 14, 19-40. [CrossRef]

14. Goh, C.; Leong, C.; Kasmin, K.; Hii, P.; Tan, O. Students' experiences, learning outcomes and satisfaction in e-learning. J. E-Learn. Knowl. Soc. 2017, 13, 117-128.

15. Paechter, M.; Maier, B.; Macher, D. Students' expectations of, and experiences in e-learning: Their relation to learning achievements and course satisfaction. Comput. Educ. 2010, 54, 222-229. [CrossRef]

16. Sun, P.C.; Tsai, R.J.; Finger, G.; Chen, Y.Y.; Yeh, D. What drives a successful e-Learning? An empirical investigation of the critical factors influencing learner satisfaction. Comput. Educ. 2008, 50, 1183-1202. [CrossRef]

17. Sepulveda, A. The Digital Transformation of Education: Connecting Schools, Empowering Learners. UNESCO. 2020. Available online: https://unesdoc.unesco.org/ark:/48223/pf0000374309 (accessed on 3 November 2020).

18. Correia, A.P. Healing the Digital Divide During the COVID-19 Pandemic. Q. Rev. Distance Educ. 2020, $21,13-21$.

19. Muresan, M.; Gogu, E. Overcoming the Digital Divide for facilitating the elearning process. In The International Scientific Conference eLearning and Software for Education; Carol I National Defence University: Bucharest, Romania, 2014; Volume 3, p. 310.

20. Journell, W. The Inequities of the Digital Divide: Is e-learning a solution? E-Learn. Digit. Media 2007, 4, 138-149. [CrossRef]

21. McKinsey \& Company. Transforming Learning through mEducation. 2012. Available online: https://www.mckinsey.com/ \{\}/ media/mckinsey/industries / public\%20and\%20social\%20sector/our\%20insights/transforming\%20learning\%20through\%20 meducation/transforming-learning-through-meducation-final.pdf (accessed on 23 November 2020). 
22. Deloitte. Global Development of AI-based Education. 2019. Available online: https://www2.deloitte.com/content/dam/ Deloitte/cn/Documents / technology-media-telecommunications / deloitte-cn-tmt-global-development-of-ai-based-educationen-191108.pdf (accessed on 17 September 2020).

23. Gold, A.H.; Malhortra, A.; Segars, A.H. Knowledge Management: An Organizational Capabilities Perspective. J. Manag. Inf. Syst. 2001, 18, 185-214. [CrossRef]

24. Liao, S.H.; Wu, C.C. The relationship among knowledge management, organizational learning, and organizational performance. Int. J. Bus. Manag. 2009, 4, 64-76. [CrossRef]

25. López-Nicolás, C.; Meroño-Cerdán, Á.L. Strategic knowledge management, innovation and performance. Int. J. Inf. Manag. 2011, 31, 502-509. [CrossRef]

26. Ngah, R.; Tai, T.; Bontis, N. Knowledge Management Capabilities and Organizational Performance in Roads and Transport Authority of Dubai: The mediating role of Learning Organization. Knowl. Process Manag. 2016, 23, 184-193. [CrossRef]

27. Rowley, J. Is higher education ready for knowledge management? Int. J. Educ. Manag. 2000, 14, 325-333. [CrossRef]

28. Kidwell, J.J.; Vander Linde, K.; Johnson, S.L. Applying corporate knowledge management practices in higher education. Educ. Q. 2000, 23, 28-33.

29. Akhavan, A.; Owlia, M.S.; Jafari, M.; Zare, Y. A model for linking knowledge management strategies, critical success factors, knowledge management practices and organizational performance; the case of Iranian universities. In Proceedings of the 2011 IEEE International Conference on Industrial Engineering and Engineering Management, Singapore, 6-9 December 2011; pp. 1591-1595.

30. Townley, C.T. Will the academy learn to management knowledge? Educ. Q. 2003, 2, 8-10.

31. Mahdi, O.R.; Nassar, I.A.; Almsafir, M.K. Knowledge management processes and sustainable competitive advantage: An empirical examination in private universities. J. Bus. Res. 2019, 94, 320-334. [CrossRef]

32. Iqbal, A.; Latif, F.; Marimon, F.; Sahibzada, U.F.; Hussain, S. From knowledge management to organizational performance. J. Enterp. Inf. Manag. 2019. [CrossRef]

33. Muqadas, F.; Rehman, M.; Aslam, U.; Ur-Rahman, U. Exploring the challenges, trends and issues for knowledge sharing: A study on employees in public sector universities. VINE J. Inf. Knowl. Manag. Syst. 2017, 47, 2-15. [CrossRef]

34. Ramjeawon, P.V.; Rowley, J. Knowledge management in higher education institutions: Enablers and barriers in Mauritius. Learn. Organ. 2017. [CrossRef]

35. Bratianu, C. Universities as learning organizations: Challenges and strategies. In Challenging the Status Quo in Management and Economics; Tritonic Publishing House: Bucharest, Romania, 2018; pp. 545-554.

36. Gurteen, D. Creating a Knowledge Sharing Culture. Available online: http://www.gurteen.com/gurteen/gurteen.nsf/id/ ksculture (accessed on 10 November 2020).

37. Tan, C.N.L. Enhancing knowledge sharing and research collaboration among academics: The role of knowledge management. High. Educ. 2016, 71, 525-556. [CrossRef]

38. Chugh, R. Do Australian Universities Encourage Tacit Knowledge Transfer? In Proceedings of the KMIS 2015-7th International Conference on Knowledge Management and Information Sharin, Lisbon, Portugal, 12-14 November 2015; pp. $128-135$.

39. Alharthi, A.D.; Spichkova, M.; Hamilton, M. Sustainability requirements for elearning systems: A systematic literature review and analysis. Requir. Eng. 2019, 24, 523-543. [CrossRef]

40. Petrides, L.A.; Nodine, T.R. Knowledge Management in Education: Defining the Landscape; Institute for the Study of Knowledge Management in Education: Half Moon Bay, CA, USA, 2003.

41. Tessier, D.; Dalkir, K. Implementing Moodle for e-learning for a successful knowledge management strategy. Knowl. Manag. E-Learn. 2016, 8, 414-429.

42. Campbell, L. What Does the " $\mathrm{e}$ " Stand for? (Report the University of Melbourne). 2004. Available online: https://taxprof. typepad.com/taxprof_blog/2020/03/coronavirus-and-the-great-online-learning-experiment.html (accessed on 26 March 2020).

43. Weichhart, G.; Stary, C.; Appel, M. The digital Dalton Plan: Progressive education as integral part of web-based learning environments. Knowl. Manag. E-Learn. 2018, 10, 25-52.

44. Sharifzadeh, M.; Safari, S. The Role of Knowledge Management Elements in the Improvement of the Faculty Members in DistanceEducation Universities) designing an appropriate model. J. Med Educ. 2019, 12, 89-102.

45. Ras, E.; Memmel, M.; Weibelzahl, S. Integration of e-learning and knowledge management-Barriers, solutions and future issues. In Proceedings of the Biennial Conference on Professional Knowledge Management/Wissensmanagement 2005, Kaiserslautern, Germany, 10-13 April 2005; pp. 155-164.

46. Al Shehab, N. How to Increase Knowledge Retention in eLearning During Covid-19 Pandemic? In Proceedings of the ECEL 2020 19th European Conference on e-Learning, Berlin, Germany, 29-30 October 2020; pp. 10-15.

47. Nunez, J.L.M.; Caro, E.T.; Gonzalez, J.R.H. From higher education to open education: Challenges in the transformation of an online traditional course. IEEE Trans. Educ. 2016, 60, 134-142. [CrossRef]

48. Guilbault, M. Students as customers in higher education: The (controversial) debate needs to end. J. Retail. Consum. Serv. 2018, 40, 295-298. [CrossRef]

49. Nixon, E.; Scullion, R.; Hearn, R. Her majesty the student: Marketised higher education and the narcissistic (dis) satisfactions of the student-consumer. Stud. High. Educ. 2018, 43, 927-943. [CrossRef] 
50. Bovill, C. A framework to explore roles within student-staff partnerships in higher education: Which students are partners, when, and in what ways? Int. J. Stud. Partn. 2017, 1, 1-5. [CrossRef]

51. Ricci, M.; St-Onge, C.; Xiao, J.; Young, M. Students as stakeholders in assessment: How students perceive the value of an assessment. Perspect. Med Educ. 2018, 7, 352-361. [CrossRef] [PubMed]

52. Pack, S.M.; Peek, S.C. Engaging Students as Stakeholders through a Student Advisory Board. J. Phys. Educ. 2020, 7, 74-81.

53. McGraw-Hill Education. Digital Study Trends Survey. 2017. Available online: https://s3.amazonaws.com/ecommerceprod.mheducation.com/unitas/highered/explore/sites/study-trends/2017-digital-trends-survey-results.pdf (accessed on 10 December 2020).

54. Rogowsky, B.A.; Calhoun, B.M.; Tallal, P. Providing instruction based on students' learning style preferences does not improve learning. Front. Psychol. 2020, 11, 164. [CrossRef]

55. Vagg, T.; Balta, J.Y.; Bolger, A.; Lone, M. Multimedia in Education: What do the Students Think? Health Prof. Educ. 2020 6, 325-333. [CrossRef]

56. Severiens, S.E.; \& Ten Dam, G.T. Gender differences in learning styles: A narrative review and quantitative meta-analysis. High. Educ. 1994, 27, 487-501. [CrossRef]

57. Keri, G. Male and female college students' learning styles differ: An opportunity for instructional diversification. Coll. Stud. J. 2002, 36, 433-442.

58. Francis, B. The gendered subject: Students' subject preferences and discussions of gender and subject ability. Oxf. Rev. Educ. 2000, 26, 35-48. [CrossRef]

59. Alkhasawneh, I.M.; Mrayyan, M.T.; Docherty, C.; Alashram, S.; Yousef, H.Y. Problem-based learning (PBL): Assessing students' learning preferences using VARK. Nurse Educ. Today 2008, 28, 572-579. [CrossRef]

60. Demirbas, O.O.; Demirkan, H. Learning styles of design students and the relationship of academic performance and gender in design education. Learn. Instr. 2007, 17, 345-359. [CrossRef]

61. Sarabi-Asiabar, A.; Jafari, M.; Sadeghifar, J.; Tofighi, S.; Zaboli, R.; Peyman, H.; Shams, L. The relationship between learning style preferences and gender, educational major and status in first year medical students: A survey study from Iran. Iran. Red Crescent Med. J. 2015, 17, e18250. [CrossRef] [PubMed]

62. Al-Saud, L.M.S. Learning Style Preferences of First-Year Dental Students at King Saud University in Riyadh, Saudi Arabia: Influence of Gender and GPA. J. Dent. Educ. 2013, 77, 1371-1378. [CrossRef]

63. Cetin, S.Y.; Erel, S. Determining the learning preferences of the students of the faculty of health sciences in Cyprus International University. SHS Web Conf. 2018, 48, 01026. [CrossRef]

64. Dalmolin, A.C.; Mackeivicz, G.A.O.; Pochapski, M.T.; Pilatti, G.L.; Santos, F.A. Learning styles preferences and e-learning experience of undergraduate dental students. Revista de Odontologia da UNESP 2018, 47, 175-182. [CrossRef]

65. Othman, R.; Shahrill, M.; Mundia, L.; Tan, A.; Huda, M. Investigating the relationship between the student's ability and learning preferences: Evidence from year 7 mathematics students. New Educ. Rev. 2016, 44, 125-138. [CrossRef]

66. Demirkan, H. An inquiry into the learning-style and knowledge-building preferences of interior architecture students. Des. Stud. 2016, 44, 28-51. [CrossRef]

67. Matthews, D.B. An investigation of students' learning styles in various disciplines in colleges and universities. J. Humanist. Educ. Dev. 1994, 33, 65-74. [CrossRef]

68. Garber, L.L.; Hyatt, E.M.; Boya, Ü.Ö. Gender differences in learning preferences among participants of serious business games. Int. J. Manag. Educ. 2017, 15, 11-29. [CrossRef]

69. Yousef, D.A. Learning Styles Preferences of Statistics Students. Quality Assurance in Education. 2016. Available online: https:/ / www.researchgate.net/profile/Darwish_Yousef/publication/299356350_Learning_styles_preferences_of_statistics_students / links/5b0d7f36a6fdcc809958d5fd/Learning-styles-preferences-of-statistics-students.pdf (accessed on 10 December 2020).

70. Gappi, L.L. Relationships between learning style preferences and academic performance of students. Int. J. Educ. Res. Technol. 2013, 4, 70-76.

71. Kolb, D.A. Learning Style Inventory; Version 3; The Hay Group: Boston, MA, USA, 1999.

72. Felder, R.M.; Soloman, B.A. Index of Learning Styles; North Carolina State University: Raleigh, NC, USA, 1991; Available online: https://www.engr.ncsu.edu/wp-content/uploads/drive/1WPAfj3j5o5OuJMiHorJ-1v6fON1C8kCN/styles.pdf (accessed on 8 February 2021).

73. Velásquez, R.M.A.; Lara, J.V.M. Knowledge management in two universities before and during the COVID-19 effect in Peru. Technology in Society 2020, 101479. Available online: https:/ /www.sciencedirect.com/science/article/pii/S0160791X20312823 (accessed on 17 December 2020).

74. Pinzaru, F.; Mitan, A. Generation Y Students: Using Facebook for Communicating with University Staff and Professors. Manag. Dyn. Knowl. Econ. 2013, 1, 221-239.

75. Moran, M.; Seaman, J.; Tinti-Kane, H. Teaching, Learning, and Sharing: How Today's Higher Education Faculty Use Social Media; Babson Survey Research Group: Babson Park, MA, USA, 2011.

76. Moghavvemi, S.; Sulaiman, A.; Jaafar, N.I.; Kasem, N. Social media as a complementary learning tool for teaching and learning: The case of YouTube. Int. J. Manag. Educ. 2018, 16, 37-42. [CrossRef]

77. Clifton, A.; Mann, C. Can YouTube enhance student nurse learning? Nurse Educ. Today 2011, 31, 311-313. [CrossRef] [PubMed] 
78. Orús, C.; Barlés, M.J.; Belanche, D.; Casaló, L.; Fraj, E.; Gurrea, R. The effects of learner-generated videos for YouTube on learning outcomes and satisfaction. Comput. Educ. 2016, 95, 254-269. [CrossRef]

79. Chtouki, Y.; Harroud, H.; Khalidi, M.; Bennani, S. The impact of YouTube videos on the student's learning. In Proceedings of the 2012 International Conference on Information Technology Based Higher Education and Training (ITHET), Istanbul, Turkey, 21-23 June 2012; pp. 1-4.

80. Wang, Q.; Woo, H.L.; Quek, C.L.; Yang, Y.; Liu, M. Using the Facebook group as a learning management system: An exploratory study. Br. J. Educ. Technol. 2012, 43, 428-438. [CrossRef]

81. Irwin, C.; Ball, L.; Desbrow, B.; Leveritt, M. Students' perceptions of using Facebook as an interactive learning resource at university. Australas. J. Educ. Technol. 2012, 28, 1221-1232. [CrossRef]

82. Richardson, J.T. Investigating the relationship between variations in students' perceptions of their academic environment and variations in study behaviour in distance education. Br. J. Educ. Psychol. 2006, 76, 867-893. [CrossRef] [PubMed]

83. Bracci, E.; Tallaki, M.; Castellini, M. Learning preferences in accounting education: A focus on the role of visualization. Meditari Account. Res. 2019, 28, 391-412. [CrossRef]

84. Göğüş, A.; Ertek, G. Learning and personal attributes of university students in predicting and classifying the learning styles: Kolb's nine-region versus four-region learning styles. Procedia-Soc. Behav. Sci. 2016, 217, 779-789. [CrossRef]

85. Göğüs, A.; Ertek, G. A Scoring Approach for the Assessment of Study Skills and Learning Styles. Int. J. Inf. Educ. Technol. 2020, 10, 715-722. [CrossRef]

86. Karagiannopoulou, E.; Milienos, F.S.; Kamtsios, S.; Rentzios, C. Do defence styles and approaches to learning 'fit together' in students' profiles? Differences between years of study. Educ. Psychol. 2020, 40, 570-591. [CrossRef]

87. Nicolescu, O.; Nicolescu, C. The specificity and typology of dynamic management studies. J. Organ. Chang. Manag. 2014, 27, 299-313. [CrossRef] 